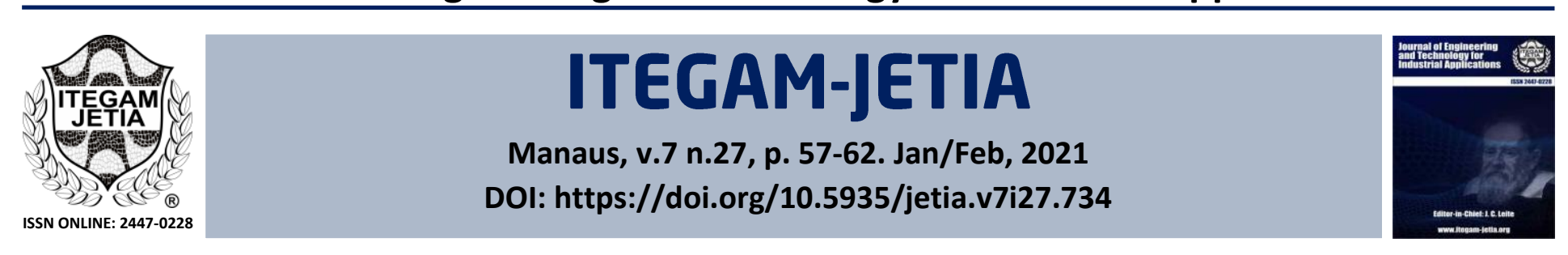

\title{
THE ANALYSIS OF THE RECENT PERIODS OF WHEAT MARKET IN TURKEY
}

\author{
Mehmet Cançelik¹, Zeliha Şahin², Mehmet Reşit Sevinç*3, Nihat Küçük ${ }^{4}$ and Mustafa Hakkı Aydoğdu ${ }^{5}$ \\ ${ }^{1}$ Department of Social Science Vocational School, Harran University. Şanlıurfa, Turkey. \\ 2, 5 Department of Agricultural Economics, Faculty of Agriculture, Harran University. Sanliurfa, Turkey. \\ ${ }^{3}$ Department of Bozova Vocational School, Harran University. Sanliurfa, Turkey. \\ ${ }^{4}$ Department of Economic Policy, Faculty of Economics and Administrative Sciences, Harran University. Sanliurfa, Turkey. \\ ${ }^{1}$ http://orcid.org/0000-0001-8158-4455 (ㅇ, ${ }^{2}$ http://orcid.org/0000-0002-9063-4474 (i), ${ }^{3}$ http://orcid.org/0000-0002-0617-7822 (1), \\ ${ }^{4}$ http://orcid.org/0000-0002-1483-0422 (10, ${ }^{5}$ http://orcid.org/0000-0002-4945-5239 (1)
}

Email: m.cancelik@harran.edu.tr, zelihasahiin@gmail.com, *rsevinc@harran.edu.tr, nihatk@harran.edu.tr, mhaydogdu@hotmail.com

\begin{tabular}{|c|c|}
\hline ARTICLE INFO & ABSTRACT \\
\hline $\begin{array}{l}\text { Keywords: } \\
\text { Consumption, } \\
\text { Prices, } \\
\text { Wheat production, } \\
\text { Trade balance, } \\
\text { Turkey. }\end{array}$ & $\begin{array}{l}\text { future of wheat production in Turkey. For this purpose, projections were made until } 2024 \\
\text { by using data between the years of } 2005 \text { and } 2019 \text {. According to the results, the wheat } \\
\text { cultivation areas decrease, and prices are rising in Turkey. On the other hand, wheat yield } \\
\text { increases compared to previous years due to factors such as the development of technology, } \\
\text { the expansion in irrigation areas, and the use of certified seeds. Wheat imports also have } \\
\text { been increased due to population growth, increases in livestock, internal processing, and the } \\
\text { development of the flour and flour products industry in Turkey. It is expected that wheat } \\
\text { imports will continue. To prevent this situation, wheat cultivation areas should be expanded } \\
\text { and producers should be supported more with public policies that increase production. For } \\
\text { this, it is necessary to increase the efficiency of agricultural extension activities, to ensure } \\
\text { the participation of farmers, and to apply competitive support policies to strategic products } \\
\text { such as wheat. }\end{array}$ \\
\hline
\end{tabular}

Copyright (C2016 by authors and Galileo Institute of Technology and Education of the Amazon (ITEGAM). This work is licensed under the Creative Commons Attribution International License (CC BY 4.0).

\section{INTRODUCTION}

Due to the climate change and droughts that have become more common globally in recent years, the issue of food safety has started to raise concerns and more frequently [1-3]. Of the approximately 1.5 billion hectares of agricultural land in the world, 718 million hectares of grain are cultivated and around 2.9 billion tons of production is made [4], [5]. Wheat is a one-year field crop that can be grown all over the world and is included in the cereals group. Anatolia, Caucasus, and western Iran are known as the first production place of wheat in the records [6-8]. Wheat is the raw material of bread, which is the main food source for humans and is used as feed in livestock and poultry. Grain and cereal products are important foods for health because they contain vitamins, minerals, carbohydrates (starch, pulp), and other nutrients and have high carbohydrate content. Therefore, grains are among the main energy sources of the body [7], [9], [10]. While corn ranks first in grain production in the world, wheat is located the first in Turkey [11]. Wheat was a crop that was mostly produced under dry farming conditions until recently, but today, with the developing technology and irrigation, significant productivity increases have been achieved in the production amount. This situation started to make wheat a more competitive product compared to other annual crops. On the other hand, although wheat is grown in every region in Turkey, the Central Anatolia region is produced the most where the continental climate is dominant [12]. 
In the consumption of wheat as food, it can be ground or peeled in various machines and offered for sale according to the purpose of use. It is also produced as well as feed for farm animals in Turkey. The straw remaining after the wheat harvest is used as cattle and ovine feed-in farms. Livestock enterprises are mostly composed of small and scattered family businesses and the production of feed crops in these enterprises is not adequate [13]. The increase in input prices, while causing a decrease in the production of fodder crops, this situation also hampers the development of animal production potential in Turkey at the desired level [14]. Another reason that makes the wheat production important in Turkey is that forage crops as the first or second product has the limited cultivation of agricultural land [15]. Barley and wheat are mostly used as fodder crops in small family businesses in animal husbandry. In this sense, wheat production also affects animal husbandry. Because grains used as feed are important for livestock businesses [16].

Turkey has become an important exporter in the world with exports of finished products based on wheat. As Turkey's most bakery products, pasta, boiled and pounded wheat, grits and biscuits are made for export. The highest increase in finished product exports was in pasta in 2018 [11]. On the other hand, wheat straw can be processed industrially and used in paper production. The multi-purpose usage of the wheat situation reveals the importance of wheat in Turkey. Since wheat has always been an important foodstuff for living things, it has been supported to be produced as a strategic product. Public support policies implemented varied according to years and conditions [17]. Therefore, wheat cultivation in Turkey is supported as a public policy. Within the scope of agricultural support payments to farmers for wheat are as follows: 190 Turkish Lira (TL)/hectare (ha) of diesel support, $80 \mathrm{TL} / \mathrm{ha}$ fertilizer support, $0.05 \mathrm{TL} / \mathrm{kg}$ difference payment support, $85 \mathrm{TL} / \mathrm{ha}$ certified seed usage support and $0,10 \mathrm{TL} / \mathrm{kg}$ certified seed production support is provided in 2020 in Turkey. 1 USD average equal to 6.96 Turkish Lira [18]. Besides, it was decided to pay 40 TL for 5 ha and above land and $10 \mathrm{TL}$ for solid organic-organomineral fertilizer support. When barley and wheat are produced as green grass as forage crops, it is given as $300 \mathrm{TL} /$ ha per year within the support program [19]. The implementation of public agricultural support cannot be said that it satisfies farmers sufficiently in Turkey [20].

Because wheat is the main nutrient, it is produced by all countries. According to the 2020 data of the Food and Agriculture Organization (FAO), the first 20 countries in terms of wheat cultivation areas in the world are given in Figure 1.

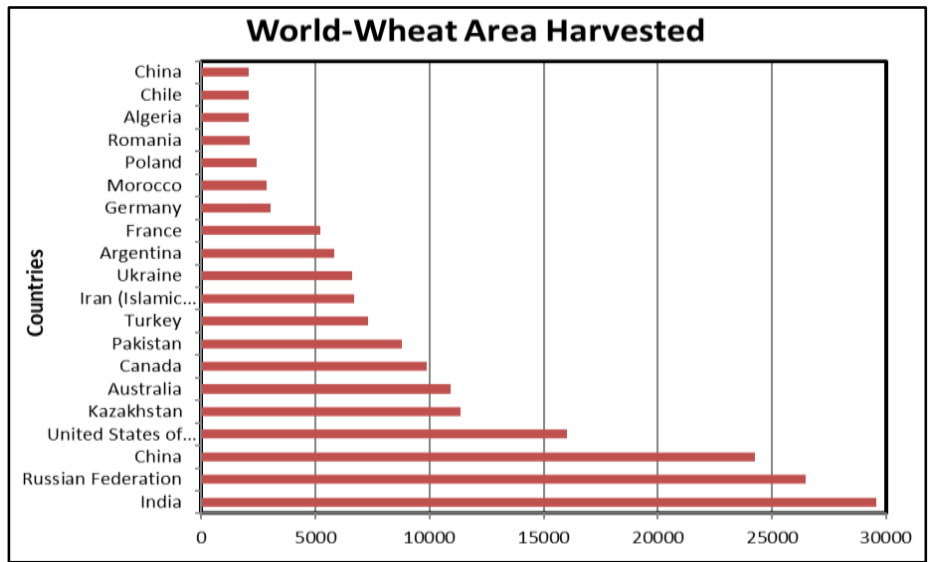

Figure 1: Cultivation areas of top 20 wheat producing countries in 2018.

Source: [21].
The amount of wheat production in Turkey is mostly determined by the nature and place of production conditions. Therefore, wheat production varies from year to year and depending on the climate. According to data from the FAO Global wheat cultivation area for Turkey, it ranks 9th in 2018. Last 14 years (2005-2018) wheat production areas in the world increased by $6.70 \%$, while wheat production area in Turkey has decreased by $20.98 \%$. This ratio was $21.09 \%$ when it is calculated according to the data of the Turkey Statistical Institute (TUIK) [12], [21]. While the wheat cultivation area increases in the world, the acreage is declining in Turkey. Although Anatolia is among the known homelands of wheat, the expansion of irrigated areas and areas for various economic reasons wheat production is declining in Turkey. The first 20 countries in terms of wheat production amount in the world are given in Figure 2.

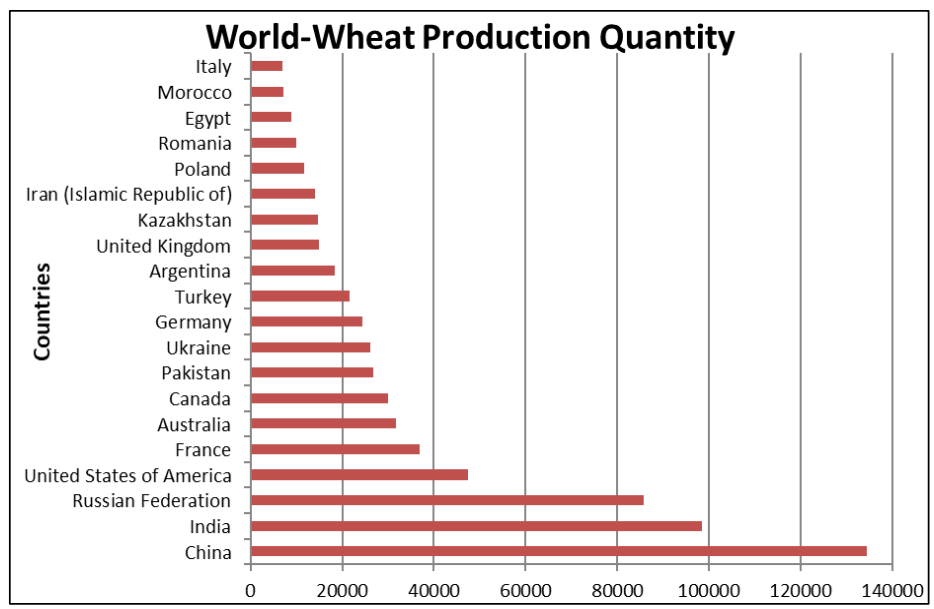

Figure 2: The production amount of top 20 wheat producing countries in 2018.

Source: [21].

The average production value of the first 20 countries has been calculated as 33514 thousand tons' for the year 2018 in Figure 2. Turkey's wheat production quantity was 21500 thousand tons in the year 2018, which was $64.15 \%$ of the average of the top 20 countries in the world. Turkey ranks 11 th in world wheat production by this amount [4]. Although wheat production in Turkey with favorable climatic conditions, its production decreases due to decrease of agricultural cultivation areas, preferring other products with high economic value instead of cultivating wheat, increase in input costs, insufficient incentives given, and not being able to combat pests sufficiently. As in all the world, as well as increases in food prices together with increasing demand being experienced in Turkey. This situation makes it obligatory for every country to produce at least enough wheat for its domestic consumption.

The purpose of this study is to evaluate the wheat market situation and evaluation of implemented policies in recent years in the world and Turkey. For this purpose, wheat production, consumption, yield, average selling price, export-import value, the foreign trade balance was investigated for Turkey. Depending on the available data, projections were made until 2024.

\section{MATERIALS AND METHODS}

In this study, data from TUIK and FAO, related sector reports, and other studies were used. Secondary data were used in this research. For this purpose, data between 2005 and 2019 were used to analyzes wheat production area, production amount (tons), 
yield per acreage $(\mathrm{kg})$, sales price $(\mathrm{kg} / \mathrm{TL})$, foreign trade balance, import, and export. As a method in the study, trend analysis was made in the Microsoft Office program with the data obtained from TUIK and FAO data. In these analyzes, projections were made until 2024, using data from 2005 and 2019. Also, other studies and researches on the subject have been used to interpret the results.

\section{RESULTS AND DISCUSSIONS}

To determine the change in Turkey by years of wheat acreage and projections to predict the future using the TUIK data for the years 2005-2019, and trend analysis has been conducted until 2024 and is shown in Figure 3.

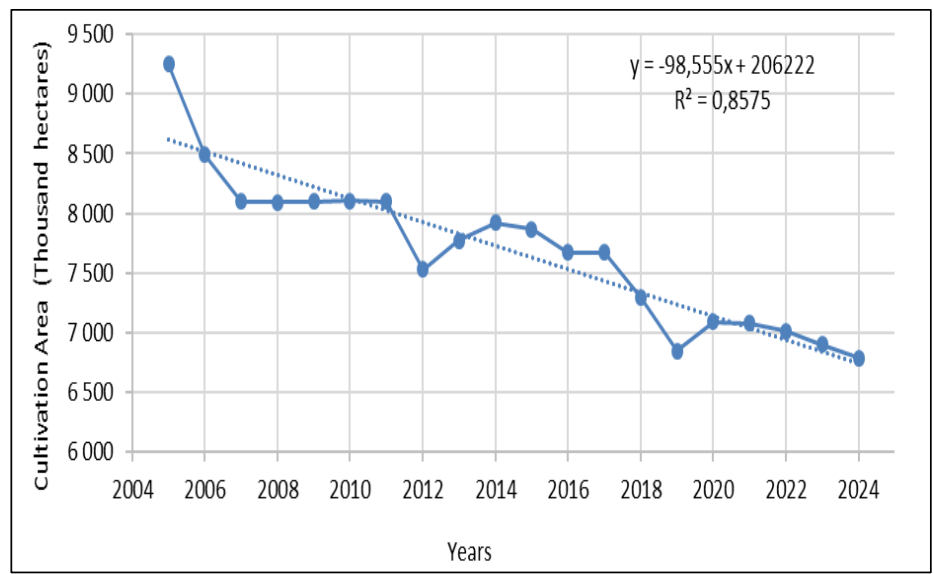

Figure 3: Wheat cultivation areas between the 2005-2024 year in Turkey.

Source: [12].

Accordingly, the wheat cultivation areas in Turkey is decreased at a rate of $12.46 \%$ between 2007 and 2005. Between the years of 2007-2011, wheat cultivation areas are generally at the same level and no significant change was observed. There was a $7.00 \%$ decrease in the cultivation area in 2012. While an increasing trend was observed in wheat cultivation areas between 2012 and 2014, it has a decreasing slope after 2014. Wheat cultivation area has reached its lowest level in 2019 in Turkey. While there is a slight increase tendency in the trend analysis to 2021, it has a decreasing slope from 2021 until the end of the analysis period [12]. The fluctuations in the wheat cultivation areas between the dates discussed also manifested themselves in the presence of animal numbers. Analysis of projections up to the year 2024 is expected to continue the downward trend in wheat-growing areas in Turkey. The regression coefficient in the projection analysis up to 2024 is 0.86 . If additional measures are not taken, it is interpreted that the decrease in the cultivation areas will continue in the future.

Data for the years 2005-2019 were used to determine the changes over the years and the average selling price of wheat in Turkey and also to estimate future periods projection. Trend analysis has been made on these data until 2024 and is given in Figure 4.

The regression coefficient of the trend analysis performed is 0.96 and shows an increasing trend. This situation is interpreted as that wheat prices will increase in the future. In general wheat sales prices between 2005 and 2019 have shown a rising slope in Turkey. This increase in prices is explained by a decrease of $11.63 \%$ in wheat production between the aforementioned periods. As prices depend on supply and demand under general economic conditions, and it is an expected situation that prices will increase as the amount of supply decreases [22].

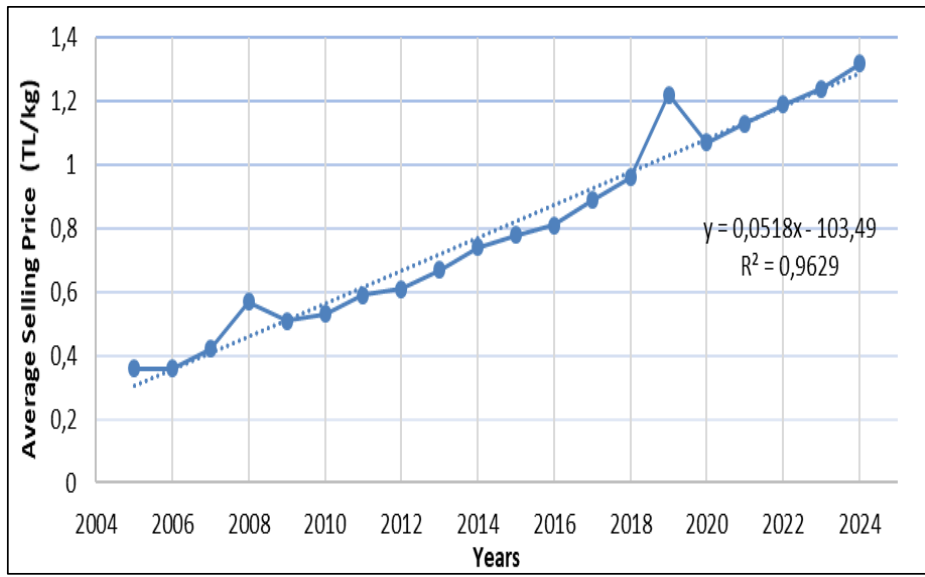

Figure 4: The average sales price of wheat in Turkey between the years 2005 to 2024 .

Source: [22].

At the beginning and the end of the research period, an increase of $237.5 \%$ in average wheat sales prices was determined. The average selling price in Turkey has not been a significant price change in 2006 compared to the previous year. An increase of $18.30 \%$ was determined in the average wheat sales price in 2007 . An increase of $35.71 \%$ was determined compared to the previous year in 2008. On the other hand, there was a $10.53 \%$ decrease in 2009 compared to the previous year. The wheat average sales price is increased by $81.13 \%$ between 2010 and 2018. An increase of $26.56 \%$ compared to the previous year was observed, and the price reached a peak with $0.96 \mathrm{TL} / \mathrm{kg}$ in 2019. According to the projections, a decrease of $14.02 \%$ is expected in 2020 compared to the previous year, while it is predicted that the average sales price will increase by $16.81 \%$ between 2021-2024 [22].

Depending on the year's wheat acreage decreased in Turkey, while increasing productivity. This situation arises due to the areas with irrigation and developing technologies in agricultural production. The data of 2005 and 2019 were used to determine the amount of change in wheat yield by year's and to estimate future projections in Turkey. Then, with these data, the yield $(\mathrm{kg} / \mathrm{ha})$ variation graph of wheat was obtained until 2024 and is shown in Figure 5 .

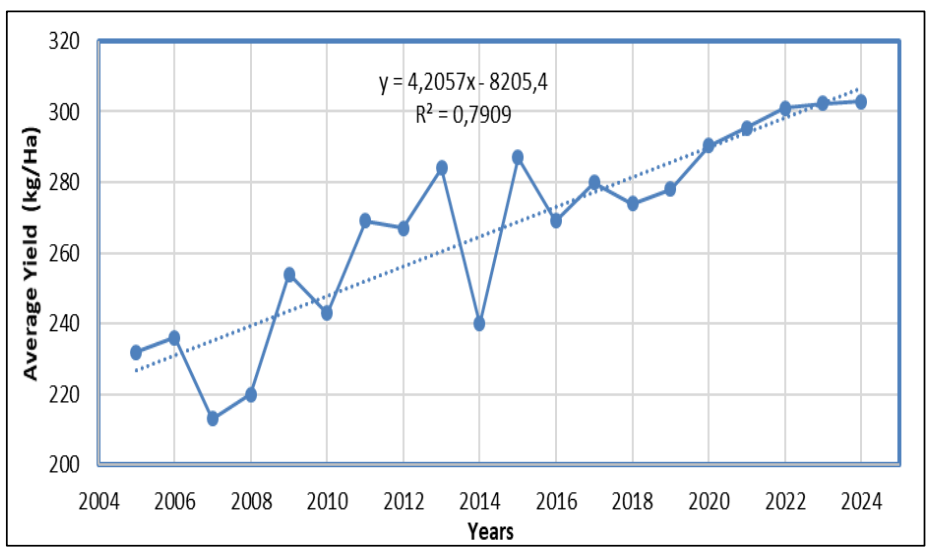

Figure 5: The average yield of wheat in Turkey between the years 2005 to 2024.

Source: [12], [23].

The yield, which was $2324 \mathrm{~kg} / \mathrm{ha}$ in 2005, increased and decreased at a fluctuating rate in the analyzed period, and reached $2772 \mathrm{~kg} / \mathrm{ha}$ in 2019. According to the data, while the yield increased by an average of $19.40 \%$ between 2005 and 2019, the 
cultivation areas decreased by $25.99 \%$. The fluctuating change in yield is explained by climatic conditions and precipitation. Because wheat production in Turkey is mostly done in dry farming conditions. It was determined that the efficiency was in an increasing trend and the regression coefficient was 0.79 in the projections made between 2005 and 2024 [12], [23]. There are many factors affecting yield in agricultural production. Soil and cultivation, agricultural struggle, fertilization, irrigation, seed improvement, mechanization, foundations that support agriculture, and easily marketable product are among the factors affecting yield [24-26]. Agricultural technologies, high-quality seeds, and inputs are predicted to be effective in this yield increase.

Wheat yield was found to be the lowest in 2007 during the research period, and the reason for this is that the precipitation in this year decreased by $8.6 \%$ compared to normal periods [27]. During the research period, the yield fluctuated continuously between 2008 and 2013 depending on the changing climate conditions, and this period's average yield increased by $29.07 \%$. On the other hand, the average yield decreased in 2014, and the largest increase in productivity was experienced in 2015. This situation can be explained by the spatial distribution of precipitation [28]. Average yield decreased in 2016 due to the distribution of precipitation globally. Turkey has received an average of $597.6 \mathrm{~mm}$ rainfall in 2016 [29]. Although the total amount of precipitation in 2017 was $506.6 \mathrm{~mm}$, which was $12 \%$ below the $574 \mathrm{~mm}$ which was the average of 1981-2010 [30], the yield was increased. On the other hand, the average rainfall was $658.7 \mathrm{~mm}$ in 2018 which was above the long-term average of $14.8 \%$ and it was $30.0 \%$ more than the precipitation in 2017 in Turkey [31]. However, unlike the increase in precipitation in 2018, wheat yield decreased by $2.27 \%$ compared to the previous year. These results are interpreted as the occurrence of rainfall based on spatial distribution except the total amount of precipitation and other factors rather than climates, such as irrigation, fertilizer, and seeds. Especially in this year, fertilizer prices in Turkey, depending on the depreciation of TL, due to increased imports. These extraordinary price increases have caused some of the farmers to give up production, or to reduce their land and the amount of fertilizer they use in production [32]. There was an increase of $1.29 \%$ in 2019 . Based on the data obtained by the projections made between the years 2020-2024 in the researched period it is estimated to be an increase in the average yield on Turkey [23].

Data for the years 2005 and 2019 were used to identify the change in the situation of wheat imports by years and to estimate future period projections in Turkey. Based on these data, trend analysis has been conducted until 2024 and is given in Figure 6.

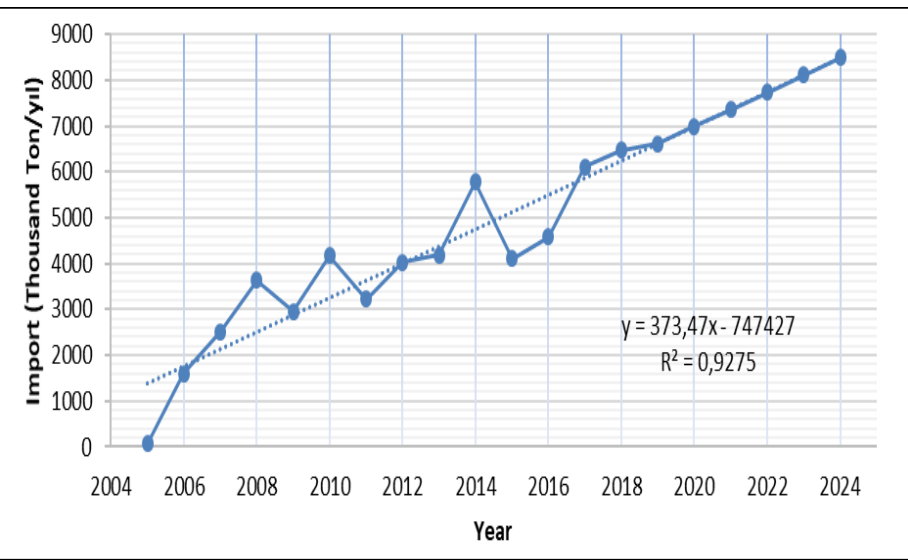

Figure 6: Wheat Import of Turkey between the years 2005-2020. Source: [23].
Although Turkey has a variable structure in terms of foreign trade was mostly wheat importer. Turkey's wheat imports, including the export processing, production areas, and quantities, vary according to years, depending on the use of domestic raw materials as food and feed. However, considering the data from the research period, the increase and decrease in the amount of imports are mostly explained by processed internally and then exports, cultivation areas, yield, and climate-based precipitation. The increase in the import rate was directly proportional to the increasing demand and the number of animals. In the researched period, the cultivation areas decreased by $25.99 \%$, and they have a decreasing slope in the future [23].

In some production periods, because wheat processing facilities operate below the current capacity, during the dry season, wheat production was at a level that cannot meet domestic consumption, therefore wheat import becomes obligatory [17]. According to the trend analysis, the regression coefficient was 0.93 , and wheat import is expected to be in an increasing slope until 2024. According to the current data, these increases stem from the increase in consumption, the decrease in the cultivation areas, the export made by internal processing, and the use of feed-in livestock breeding.

The import and export of data of 2005 and 2019 years were used for the determination of the change in the trade balance over the years and future projections estimate in Turkey. For this purpose, trend analysis has been made until 2024, and it is given in Figure 7.

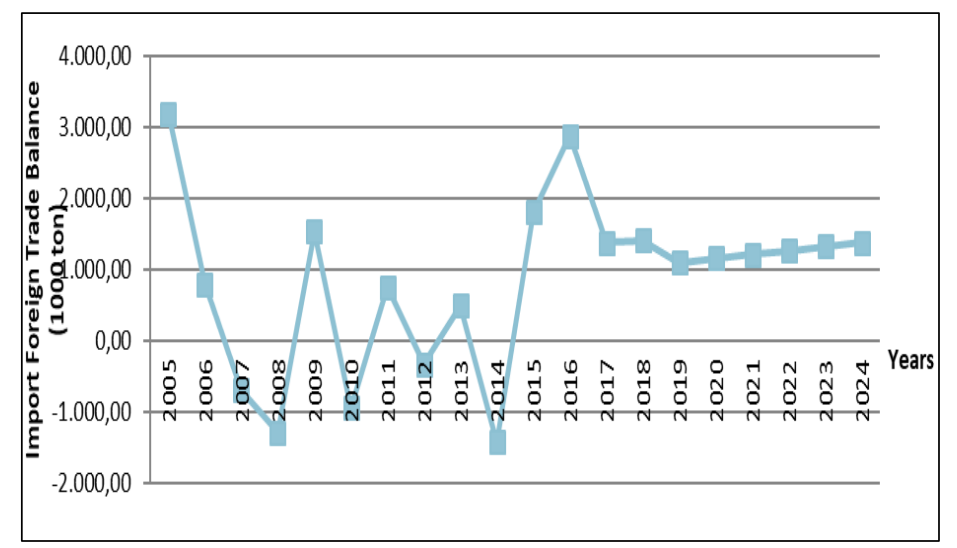

Figure 7: Wheat trade balance of Turkey Between the years 20052024.

Source: [23].

Turkey within the researched period, the trade balance has shown a fluctuating structure, generally has been an importer. The essence of these fluctuations is the imbalances in the production amount due to climate conditions, and the increase and decrease in the cultivation areas due to the farmers preferring other products with high economic value supported by the state instead of wheat. In the projections made for the years between 2020 and 2024, it is predicted that the foreign trade balance deficit will increase by $19.23 \%$ [23].

\section{CONCLUSIONS}

Although Turkey to take place within the first 10 countries in the world wheat acreage, wheat production amount is lower than the rate it. The cultivated wheat variety, climatic conditions, and dry farming are some of the main reasons why the wheat yield is below the world average. Concerning the trend analysis, wheat acreage decreases with each passing day and average sales prices 
are increasing in Turkey. On the other hand, it has been determined that wheat yield has increased compared to previous years due to factors such as the development of technology, increase in irrigation areas, and the use of certified seeds. In Turkey, population growth, the increase in the feed and livestock, flour and flour products in wheat imports have increased steadily with the development of the industry next year and is expected to continue this growth. Due to demand based on population growth, the increase in the feed and livestock, flour and flour products with the development of the industry has shown a continuous increase in wheat imports, and this increase is expected to continue in imports for the coming years in Turkey. To prevent this situation, wheat cultivation areas should be expanded and producers should be supported more with public policies that increase production. This includes increasing the efficiency of agricultural extension activities, ensuring the participation of farmers [33], and applying competitive support policies to strategic products such as wheat.

\section{AUTHOR'S CONTRIBUTION}

Conceptualization: Mehmet Cançelik, Zeliha Şahin and Mustafa Hakkı Aydoğdu.

Methodology: Mehmet Cançelik, Mehmet Reşit Sevinç, Nihat Küçük and Mustafa Hakkı Aydoğdu.

Investigation: Mehmet Cançelik, Zeliha Şahin and Nihat Küçük. Discussion of results: Mehmet Cançelik and Mehmet Reşit Sevinç.

Writing - Original Draft: Mehmet Cançelik, Mehmet Reşit Sevinç and Mustafa Hakkı Aydoğdu.

Writing - Review and Editing: Mehmet Cançelik, Mehmet Reşit Sevinç and Mustafa Hakkı Aydoğdu.

Resources: Mehmet Reşit Sevinç, Zeliha Şahin and Nihat Küçük. Supervision: Mehmet Cançelik.

Approval of the final text: Mehmet Cançelik, Zeliha Şahin, Mehmet Reşit Sevinç, Nihat Küçük and Mustafa Hakkı Aydoğdu.

\section{REFERENCES}

[1] M.H. Aydoğdu, "Farmers' risk perception and willingness to pay for environment: Case study of GAP-Sanliurfa, Turkey," Fresenius Environmental Bulletin, vol. 25, no. 12, pp. 5449-5455, 2016.

[2] M. H. Aydoğdu, "Farmers' attitudes to the pricing of natural resources for sustainability: GAP-Şanlıurfa sampling of Turkey," Water, vol. 11, no. 9, Art. no. 9, Sep. 2019, doi: 10.3390/w11091772.

[3] M. H. Aydoğdu and K. Yenigün, "Farmers' risk perception towards climate change: A case of the GAP-Şanlıurfa region, Turkey," Sustainability, vol. 8, no. 8, Art. no. 8, 2016, doi: 10.3390/su8080806.

[4] Food and Agriculture Organization (FAO), "Statistical Databases," 2016. http://www.fao.org/faostat/en/\#data/QC (accessed Jan. 04, 2018).

[5] Ö. D. E. Köse and Z. Mut, “Tahıl ve tahıl ürünlerinin insan beslenmesi ve sağlık açısından önemi, Yozgat'ta tahılların durumu," in Bölgesel Kalkınma ve SosyoKültürel Yapı, Yozgat, May 2018, vol. 1, pp. 1121-1130.

[6] B. Atar, "Gıdamız buğdayın, geçmişten geleceğe yolculuğu," Yalvaç Akademi Dergisi, vol. 2, no. 1, Art. no. 1, Dec. 2017

[7] F. Özberk, A. Karagöz, İ. Özberk, and A. Atli, "Buğday genetik kaynaklarından yerel ve kültür çeşitlerine; Türkiye'de buğday ve ekmek," Tarla Bitkileri Merkez Araștırma Enstitüsü Dergisi, vol. 25, no. 2, Art. no. 2, Dec. 2016.

[8] A. T. Özcan, “Altın Orda Hanlığı zamanında Karadeniz'in Kafkasya sahillerinde Cenovalı tüccarlar, kolonileri ve ticari yaşam," Marmara Türkiyat Araştırmaları Dergisi, vol. 7, no. 1, Art. no. 1, Jun. 2020, doi: 10.16985/mtad.752865.

[9] G. Kotancılar, İ. Çelik, and Z. Ertugay, "Ekmeğin besin değeri ve beslenmedeki önemi," Atatürk Üni.Zir.Fak.Der., vol. 26, no. 3, pp. 431-441, 1995.
[10] A. Keçeli, "A review on the bioactive, antioxidant properties of einkorn (triticum monococcum 1. ssp. monococcum) populations and using in organic agriculture," Turkish Journal of Agriculture - Food Science and Technology, vol. 7, no. 12, Art. no. 12, Dec. 2019, doi: 10.24925/turjaf.v7i12.2111-2120.2833

[11] Toprak Mahsülleri Ofisi Genel Müdürlüğü (TMO), “2018 Hububat Sektör Raporu," Mar. 2019. https://www.tmo.gov.tr/Upload/Document/hububatsektorraporu2018.pdf (accessed Dec. 17, 2020)

[12] TUIK, "Crop production statistics," 2020 https://biruni.tuik.gov.tr/medas/?kn=92\&locale=tr (accessed Jul. 09, 2020)

[13] M. H. Aydoğdu, İ. Aydoğdu, C. A. Cevheri, M. R. Sevinç, and N. Küçük, "Şanlıurfa'daki yem bitkileri eken çiftçilerin sosyo-ekonomik profilinin analizi," Journal of Ekonomi, pp. 10-15, Mar. 2020.

[14] M. H. Aydoğdu, İ. Aydoğdu, and C. A. Cevheri, "Analysis of factors affecting the production of forage crops of farmers: GAP-Şanliurfa Sampling of Turkey," in Academic Studies in Economics and Administrative Sciences, 1st ed., H. Babacan and Y. A. Unvan, Eds. Cetinje-Montenegro: Ivpe Cetinje, 2020, pp. 142-154.

[15] M. H. Aydoğdu and N. Küçük, "General analysis of recent changes in red meat consumption in Turkey," IOSR Journal of Economics and Finance (IOSR-JEF), vol. 9, no. 6-IV, pp. 1-8, 2018, doi: 10.9790/5933-0906040108.

[16] M. H. Aydogdu and Z. Sahin, "General analysis of the recent changes of barley productions and consumptions in Turkey," IOSR Journal of Agriculture and Veterinary Science (IOSR-JAVS), vol. 13, no. 1, pp. 14-19, 2020.

[17] S. Duru, A. Gül, and S. Hayran, “Türkiye'de buğday ve buğday mamulleri dıș ticaret yapıs1," Bilecik Şeyh Edebali Üniversitesi Sosyal Bilimler Dergisi, vol. 4, no. 2, Art. no. 2, Dec. 2019, doi: 10.33905/bseusbed.563347.

[18] Anonymous, "2020 USD - Dollar exchange rates archive," 2020 https://paracevirici.com/doviz-arsiv/merkez-bankasi/gecmis-tarihli-

doviz/2020/amerikan-dolari (accessed Dec. 17, 2020).

[19] Republic of Turkey Ministry of Agriculture and Forestry, "Domestic Certified Seed Use Support," 2020. https://www.tarimorman.gov.tr/Konular/TarimsalDestekler/Diger-Tarimsal-Amacli-Destekler/Yurtici-Sertifikali-Tohum-KullanimDestegi (accessed Dec. 17, 2020)

[20] G. Sevinç, M. H. Aydoğdu, M. Cançelik, and M. R. Sevinç, "Farmers' attitudes toward public support policy for sustainable agriculture in GAP-Şanlıurfa, Turkey,' Sustainability, vol. 11, no. 23, Art. no. 23, Jan. 2019, doi: 10.3390/su11236617.

[21] Food and Agriculture Organization (FAO), "Wheat production quantity and area harvested," 2020. http://www.fao.org/faostat/en/\#data/QC (accessed Nov. 15, 2020).

[22] TUIK, "Agricultural price statistics," 2020 https://biruni.tuik.gov.tr/medas/?kn=110\&locale=tr (accessed Jul. 06, 2020).

[23] TUIK, "Agricultural product balance tables," 2020 https://biruni.tuik.gov.tr/medas/?kn=104\&locale $=\operatorname{tr}$ (accessed Jul. 06, 2020).

[24] Z. Bayramoğlu, "Tarımsal verimlilik ve önemi," Selcuk Journal of Agriculture and Food Sciences, vol. 24, no. 3, Art. no. 3, Aug. 2010.

[25] H. P. Doğan, M. H. Aydoğdu, M. R. Sevinç, and M. Cançelik, "Farmers' willingness to pay for services to ensure sustainable agricultural income in the GAPHarran Plain, Sanlıurfa, Turkey," Agriculture, vol. 10, no. 5, Art. no. 5, May 2020, doi: 10.3390/agriculture10050152.

[26] S. Cengiz and C. M. Baydur, "Kırdan kente göç ve tarımsal verimlilik: Türkiye örneği,” Ç.Ü. Sosyal Bilimler Enstitüsü Dergisi, vol. 19, no. 2, pp. 85-98, Oct. 2010

[27] Republic of Turkey General Directorate of State Meteorological Service, "2008 climate assessment report," 2009. https://www.mgm.gov.tr/files/iklim/2008-yiliiklim-degerlendirmesi.pdf (accessed Nov. 15, 2020).

[28] Republic of Turkey General Directorate of State Meteorological Service, "Climate assessment for 2016, https://mgm.gov.tr/FILES/iklim/yillikiklim/2015-iklim-raporu.pdf (accessed Nov. $15,2020)$.

[29] Republic of Turkey General Directorate of State Meteorological Service, "Climate Assessment for 2016,", 2017 
https://mgm.gov.tr/FILES/iklim/yillikiklim/2016-iklim-raporu.pdf (accessed Jul. $15,2020)$.

[30] Republic of Turkey General Directorate of State Meteorological Service, "Climate assessment for 2017," 2018. https://mgm.gov.tr/FILES/iklim/yillikiklim/2017-iklim-raporu.pdf (accessed Jul. $15,2020)$.

[31] Republic of Turkey General Directorate of State Meteorological Service, "Climate assessment for 2019," 2020. https://mgm.gov.tr/FILES/iklim/yillikiklim/2019-iklim-raporu.pdf (accessed Jul. $15,2020)$.

[32] Tarsus Commodity Exchange, "2019 Wheat condition asssessment report," 2020.

http://tarsusticaretborsasi.com/DOSYALAR/pdf/2019\%20BUGDAY\%20RAPOR. pdf (accessed Jul. 30, 2020).

[33] M. H. Aydoğdu, "Evaluation of farmers' willingness to pay for agricultural extension services in GAP-Harran plain, Turkey," Journal of Agricultural Science and Technology, vol. 19, no. 5, pp. 785-796, 2017. 